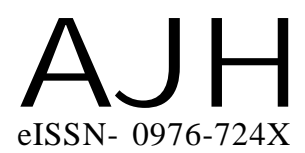

Received : 19.05.2014

Revised : 00.00.2014

Accepted : 00.00.2014

Members of the Research Forum

Associated Authors:

${ }^{1}$ Anand Agricultural University, ANAND (GUJARAT) INDIA

Author for correspondence B. SINGH

Anand Agricultural University, ANAND (GUJARAT) INDIA
THE ASIAN JOURNAL OF HORTICULTURE

Volume 9 | Issue 2 | Dec., 2014 | 510-511

Visit us -www.researchjournal.co.in

\title{
Effect of PGRs on reduction of fruit drop in mango
}

\section{cV. MALLIKA}

\section{S.P. BHAMARE ${ }^{1}$, H.C. PATEL ${ }^{1}$ AND B. SINGH}

ABSTRACT : Fruit drop has emerged as a major problem in almost all cultivars of mango. It is mainly due to heavy competition among growing fruits but may also be attributed to weather stress during development of fruits, deficient nutrition, windy location, hail storms, cloudy weather and attack of insect pests. Mallika mainly grown in Madhya Pradesh, Jharkhand, Odisha, West Bengal and Gujarat is also highly vulnerable to fruit drop. In a study conducted at Horticultural Research Farm of BA College of Agriculture, Anand Agricultural University, Anand, India, in the Kharif season of year 2011, influence of plant growth regulators (PGRs) like GA-3, NAA and 2, 4-D was tested on fruit retention in Mallika Mango. Maximum fruit retention was observed in treatment NAA@20mg/l followed by GA-3 at $25 \mathrm{mg} / \mathrm{l}$.

KEY WORDS : Competition, Stress, Nutrition, Mallika

HOW TO CITE THIS ARTICLE : Bhamare, S.P., Patel, H.C. and Singh, B. (2014). Effect of PGRs on reduction of fruit drop in mango cv. MALLIKA. Asian J. Hort., 9(2) : 510-511. 